\title{
Party Elites and the Search for Credibility: Plaid Cymru and the SNP as New Parties of Government
}

\section{Author Biography}

Craig McAngus is a Research Fellow in the School of Applied Social Science, University of Stirling

\section{Abstract}

Stateless Nationalist Regionalist Parties (SNRPs) are widely considered as mainstream political actors, and their ideological and strategic development in this regard has been well documented by scholars. However, little attention has been paid to how party elites view such processes. Adopting a comparative case study approach, this paper looks at the case of Plaid Cymru and the Scottish National Party (SNP), both of whom entered government for the first time in 2007. Drawing on original and extensive elite interview data, the paper examines how elites in both parties attempted to use the transition to government to portray their respective parties as mainstream and credible. The paper finds that this desire is driven largely by a desire to change historically embedded stereotypes, but also, in the case of the SNP, to further the party's primary goal of Scottish independence. In the case of Plaid Cymru, having to become a junior coalition partner meant that the party felt obliged to take up stereotypical portfolios which undermined, in part, the purpose of governmental participation for some elites.

\section{Introduction}

Stateless Nationalist Regionalist Parties (SNRPs) across Europe cannot, on the whole, be considered 'niche' political parties in the sense that they espouse broad policy platforms, position themselves firmly and clearly on the ideological spectrum, and participate in government at different institutional levels.

McAngus C (2016) Party elites and the search for credibility: Plaid Cymru and the SNP as new parties of government, British Journal of Politics and International Relations, 18 (3) pp 634-649. Copyright (C 2016 The Author. Reprinted by permission of SAGE Publications. https://doi.org/10.1111/1467-856X.12070 
Rather than being seen as outsider parties (McDonnell and Newell, 2011), these parties are generally seen as 'mainstream' (Elias and Tronconi, 2011a) and 'normal' (Hepburn, 2009) political actors.

Although there are exceptions, Elias and Tronconi (2011: 508) make the point that behaving in this way is a choice that parties make. However, these choices are probably more the embodiment of historical imperatives rather than rational decisions made in the context of new and evolving political circumstances and institutional arrangements. Indeed, according to Ware (1987: 1), political parties are 'the product of a specific historical experience which is not replicated elsewhere' and thus are the products of their own history.

Literature on SNRPs has examined this party family in a comparative manner (De Winter and Türsan 1998; De Winter et al. 2006), their relationship with European integration (Lynch 1996; Elias 2009a; De Winter and Gomez-Reino Cachafeiro: 2002) and more recently on the strategic challenges that new and regionalized 'spaces for politics' (Carter and Pasquier, 2010) bring to this party type (Hepburn, 2009; Jeffrey 2008). Furthermore, a new strand of literature on SNRPs considers their status as parties of government (Elias and Tronconi, 2011a, Toubeau, 2011). Although this extensive body of literature collectively accounts for the development of SNRPs into mainstream actors and parties of government, little attention has been paid to the importance of mainstreaming and governmental participation from the point of view of party elites. It is this gap that this paper aims to fill by assessing how two elites in two SNRPs, Plaid Cymru and the SNP, used the transition into being parties of government as mechanisms to attempt to address and overcome negative stereotypes they believed the public had of their respective parties. 
Adopting a comparative case study approach (Yin, 2009) and utilising extensive elite interview data, this paper examines the cases of Plaid Cymru and the Scottish National Party (SNP). Both parties provide an interesting and helpful comparison in that they both entered into government for the first time in their respective histories in 2007 . The theoretical question will develop a hypothesis which suggests that Plaid Cymru and the SNP would attempt to use governmental status as a mechanism to overcome negative perceptions of their parties. The empirical analysis will then 'test' this hypothesis. The hypothesis will be addressed in the context of further understanding the processes of becoming mainstream and normal political parties by examining what crossing the 'threshold of governance' (Deschouwer, 2008) meant for Plaid Cymru and the SNP.

The paper is organised into four parts. Firstly, a discussion of the relevant theoretical literature is offered which will provide a framework for the analysis. The second section provides a brief overview of the methods and data utilised in this paper. The third section looks at the historical development of both parties under investigation and argues that they became fully-fledged mainstream political actors by the 1960s in order to attract support away from and thus compete with state-wide parties in UK general elections. This section also considers the relevance of the creation of the National Assembly for Wales (NAW) and the Scottish Parliament. The fourth section provides the empirical analysis, and focuses on elite views regarding the relevance of governmental participation for both parties. As this section will show, governmental participation, according to party elites, was a key mechanism for achieving credibility amongst the electorate and overcoming stereotypes that party elites felt that the electorate held. In the case of Plaid Cymru specifically, governmental status was a mechanism that, for some elites, could be used to educate some elements of the party that were sceptical of taking up 
office, while for the SNP government was perceived as a necessary step in Scotland becoming a more self-confident nation on the route to independent statehood.

\section{Party elites and the use of government as a mechanism for promoting credibility}

In the introduction to a special edition of Regional and Federal Studies, Hepburn (2009) adopts the analogy 'niche to normal' to describe the development of SNRPs. In their formative years, according to Hepburn (2009: 489), these parties would claim 'ownership' of the singular issue of territory before 'thickening' (cf. Freeden, 1998) their ideological profile over time in order to electorally compete with state-wide parties and thus, presumably, become 'normal'. According to Meguid (2005: 374-348), niche parties reject class-based politics, rely on novel issues that do not coincide with existing lines of political division, and adopt policies on a limited number of issues. Hepburn (2009: 485) rightly criticises research that includes SNRPs in this category simply based on an overriding emphasis on their demand for self-government (see Adams et al, 2006 and Wagner, 2012). In short, if SNRPs were 'niche' actors in the past, the creation and extension of layers of multi-level government, particularly sub-state electoral arenas, has certainly cemented their status as 'normal' today. In the case of Plaid Cymru and the SNP however, both parties became normal political actors decades ago as will be discussed in the historical background section.

The notion of 'niche to normal' cannot be considered a theory since it does not predict nor explain the development of SNRPs. However, it is useful as a broad analogy in the sense that it implies some sort of 'journey' that SNRPs embark upon throughout their lifespan. Indeed, literature on party development draws upon the notion of a developmental journey to analyse different phases of a party's lifespan. For example, Pedersen's (1982) 'party lifespan' and Sartori's (1976) 'potential' model invoke similar yet more intricate approaches. Following from Pedersen and Sartori, Deschouwer (2008) develops a more 
intricate model which uses Sartori's 'blackmail potential' and 'coalition potential' as a way to differentiate between different aspects of Pedersen's 'threshold of relevance', whilst adding a further step on the journey: the 'threshold of governance'. Elias and Tronconi's (2011b) compilation of SNRP case-studies, for example, adopts Deschouwer's integrated (see table 1) approach for the analysis of the lifespan of a range of SNRPs in Europe. Hepburn's analogy of 'niche to normal' is not vastly different in terms of general principle but does lack the detail required of a theoretical framework.

Table 1: Deschouwer's (2008) integrated party lifespan model (as shown in Elias and Tronconi, 2011b)

i) Threshold of declaration: a group declares that it will participate in elections;

ii) Threshold of authorisation: the party fulfils the legal regulations and other requirements in order to be able to participate in elections;

iii) Threshold of representation: the party is able to gain seats in parliament;

iv) Threshold of relevance: the presence of the party in the party system affects existing patterns of party competition, either due to impact on government policy output or government formation iv-a) blackmail potential: when a party forces other political parties to respond to it; iv-b) coalition potential: a party is seen as possible governing coalition partner;

v) Threshold of governance: when a party enters government

In stating that SNRPs are no longer niche actors, Hepburn does not then go on to outline with any clarity what being 'normal' actually means. Indeed, the definition of 'normal' is taken for granted in the sense that it means, basically, not 'niche'. SNRPs take up a position on the left-right scale, promote policies 
that can be considered 'mainstream', and promote wide-ranging policy platforms that certainly cannot be considered 'limited'. Elias and Tronconi's (2011a) contribution pushes the field forward in this regard by offering an analysis of SNRPs as parties of government. One of their key conclusions is that SNRPs in government face very similar pressures as those that their state-wide counterparts face. In this respect, the experience of government and the different strategic trade-offs (Strøm and Müller, 1999) experienced by SNRPs does little to differentiate them from other party types. These findings suggest that what is 'normal' for an SNRP is 'normal' for a non-SNRP.

Elias and Tronconi (2011a) do make one qualification however. In some cases, the pressures of government become more acute for an SNRP that is experiencing government for the first time. Indeed, literature on parties that go into government for the first time (Bolleyer, 2008; Deschouwer, 2008) predicts that these parties will be susceptible to a range of vulnerabilities given that government is an entirely new experience and can represent an end to the party's previous status and identity, signalling almost a brand new party (Deschouwer, 2008: 5-6). Of course, this applies to any party entering government for the first time. However, the notion of 'vulnerabilities' has been discovered in research focussing on SNRPs. According to McAngus (2013), Plaid Cymru experienced significant organisational vulnerabilities and struggled to formulate a coherent vote-seeking strategy as a junior coalition partner, a status that Buelens and Hino (2008) suggest often leads to electoral setbacks. Indeed, Plaid Cymru lost 4 seats at the 2011 Welsh election and took up opposition status once again. This fate was not shared by the SNP, who were able to build on their first term in office as a single-party minority government and win a majority of seats at the 2011 Scottish election (Johns et al, 2013). 
The fact that Plaid Cymru and the SNP entered government for the first time in 2007 is a crucial one. Despite having becoming mainstream actors decades before, as the next section will illustrate, entering into government for the first time is a major milestone in the history of a party. Indeed, it can only happen once. Therefore, the response of party elites to this new status is likely to stem from the obvious but nonetheless crucial fact that the party has never experienced something quite like this before. In this respect, the experience and understanding of elites of SNRPs like Plaid Cymru and the SNP is likely to be no different to any other party type that happens to cross this Rubicon. However, SNRPs are somewhat different from other party types in that they hold clearly definable and distinct 'primary goals' (Harmel and Janda, 1994) that override other policy areas (cf. Duncan, 2007: 71). Indeed, Müller-Rommel (1998: 18) defines SNRPs as 'parties that refer to geographically concentrated minorities which challenge the working order, even the democratic order, by demanding recognition of their cultural identity'. In addition, SNRPs articulate discontent at the constitutional status quo of their 'territory', advocating anything from cultural autonomy to national independence (Rokkan and Urwin 1983: 141). In this respect, it would be expected that the transition to government and how elites understand and articulate the significance of such an event would include, at the very least, a link to the primary goal of the party. Both Plaid Cymru and the SNP both advocate independent statehood for Wales and Scotland respectively as their primary objectives (Plaid Cymru, 2013; SNP; 2009), with Plaid Cymru also committed to 'a bilingual society by promoting the revival of the Welsh language' (Plaid Cymru, 2013).

The fact that the parties under investigation advocate independent statehood means that they pose a significant threat to the territorial integrity of the UK, as well as presenting an even greater threat to state-wide parties that goes beyond simple electoral competition. For this reason alone, it has been a 
rational response for state-wide parties to ridicule and attempt to humiliate these parties in order to portray them as extreme, incompetent and unfit to hold public office to the electorate. Indeed, research by Rahn (1993) shows that stereotypes that individuals hold about particular parties can have an extensive influence on how they process information. Literature on framing (Druckman, 2001) also suggests that the amount of trust and credibility apportioned to a source of information is likely to affect how successfully that source can favourably frame an issue. Therefore, as well as the process of actually becoming credible in policy and strategy terms, something that can be empirically assessed and somewhat 'measured' from an outside perspective, the process of becoming a government for the first time is likely to be a mechanism that a party will use to rectify some of these perceived perceptions of themselves. As well as using governmental office in an instrumental sense (Strøm and Müller, 1999: 6) to legislate on primary goals and set a favourable agenda for further constitutional reform (Elias and Tronconi, 2011a; Toubeau, 2011), the process of changing perceptions of the party involves using what Strøm and Müller (1999: 6) describe as the 'intrinsic' value of public office. The hypothesis of this paper is, therefore, is thus: Plaid Cymru and the SNP will attempt to use governmental status as a mechanism to overcome negative perceptions of their parties that they believe exists.

Following the next section, which outlines the methodological approach used in this paper, a brief historical overview of both parties will be provided. The purpose of this section is to highlight that both parties did indeed become mainstream and normal actors decades before entering into government. The processes leading to these developments were different in both parties, but the desire to compete with the state-wide parties at UK general elections is one that is shared. Indeed, as the empirical section will show, entering into government offered an opportunity for elites to dispel myths and perceptions 
about their parties, examples of which are offered at this point, that perhaps prevented them from being seen as 'mainstream' and 'normal' in the eyes of a sceptical electorate.

\section{Methods and Data}

The paper adopts a comparative case study approach as its broad research design (Yin, 2009). The bulk of the empirical analysis is based upon interviews with Plaid Cymru and SNP elites, as well as appropriate documentary data for triangulation when possible (Scott, 1990). The interviewees consisted of Plaid Cymru Members of the NAW (AMs), SNP Members of the Scottish Parliament (MSP) who were approached for interview because of their unique insight (King and Horrocks, 2010; Weiss, 1994). A number of the interviewees in both parties are, on in Plaid Cymru's case were, senior government ministers. The Plaid Cymru interviews were carried out in September and October 2011, whilst the SNP interviews were carried out between August 2011 and July 2012. A total of 15 interviews are drawn upon, eight from the SNP and 7 from Plaid Cymru. All interviewees were granted anonymity, and reference to each interview is given by the general position of the interviewee.

\section{Becoming mainstream political actors}

Plaid Cymru was formed in August 1925 by a complex aggregate of individuals representing different organisations with the common goal of establishing a Welsh government (McAllister, 2001: 23). The party was born into a Wales of political, industrial and social turmoil and was itself a by-product of that turmoil (Davies, 1983: 3). The SNP began its life a decade later in April 1934; the result of an amalgamation between the National Party of Scotland (NPS) and the Scottish Party which were themselves the products of a patchwork of pre-existing political organisations, such as the Scottish Home Rule Association and the Scots National League (Finlay, 1994; 2009). Both organisations had 
difficult beginnings, the most pressing issue for both being financial survival and the ability to stand candidates for elections. Furthermore, both organisations had strategic and existential issues to contend with. Davies (1983: 261) argues that labeling Plaid Cymru a political party before the end of the Second World War was a misnomer, and that it existed as little more than 'an educational/cultural movement' during the 1920s and 1930s. Similarly, Finlay (1994: 251) argues that the development of the Scottish nationalist movement between 1919 and 1942 was coloured by divisiveness and a lack of coherence over its ultimate purpose. However, the 1940s saw both parties begin to develop political parties.

In 1945, Gwynfor Evans took up the presidency of Plaid Cymru, and remained in this position for an impressive 37 years. It was this period that represented the most definitive shifts in terms of modernisation and party development (McAllister, 2001: 63). Despite some calls from elements in the party in the 1960s that 'electoral politics be abandoned in favour of non-constitutional modes of action as a more effective means of advancing the cause of Welsh nationalism' (Elias, 2011: 261), the post-war period represented a period where Plaid Cymru adopted a broad policy profile in order to compete electorally across Wales. According to McAllister (2001: 159), the party 'only began to clarify its precise blueprint in earnest during the 1970s' when the party had a consistent but limited presence in terms of seats in the UK's House of Commons. Another significant development occurred in 1962 when Saunders Lewis, former president of the party, made his famous 'fate of the language' radio address which facilitated the creation of Cymdeithas yr laith Gymraeg (the Welsh Language Society) who exist to this day as a pressure group concerned with the protection and promotion of the Welsh language. The creation of this group meant that Plaid Cymru could 'scale down its own campaigns for the language and develop more fully other policies related to the goal of self-government', as well as wider economic 
concerns (McAllister, 2001: 104). By the 1970s, Plaid Cymru could be described as a mainstream, normal political actor in the sense that it had adopted a wide-ranging policy profile and competed on existing lines of political division.

Despite these mainstreaming processes, a key problem for Plaid Cymru was creating a narrative that could resonate throughout the whole of Wales. The eminent Welsh historian, John Davies (1993: 500) claimed that defining a common Welsh experience in the 20th century was akin to an exercise in metaphysics, largely due to the lack of a Welsh sense of institutional difference compared to the rest of the UK. Historically, the Welsh language and non-conformity with the established Church of England has made Wales 'different' (Davies, 1993: 168; Mitchell, 2009: 8), and Plaid's electoral strength emanated from constituencies in North and West Wales which still had a high proportion of Welsh speakers. Dafydd Elis-Thomas, party president from 1984 to 1990 was convinced that, for Plaid to succeed, the party needed to create nothing less than a 'new political tradition' in Wales (Evans, 2008: 440) and embrace politics of the 'New-Left'. This period saw Plaid Cymru become a popular political option for feminists; LGBT rights activists; environmentalists and other radical elements in Welsh society (McAllister, 2001: 79-81, Van Atta, 2003). Elis-Thomas wanted to develop Plaid Cymru into a party that would compete with Labour, and in this sense the party has certainly developed into a party that can be firmly placed on the left of the political spectrum. Indeed, Sandry (2011) argues that Plaid Cymru is more of a socialist party than a nationalist one, and in this sense the party cannot be described as a 'niche' political actor. However, despite these developments, analysis of interview evidence will show that Plaid Cymru is still a party that cares deeply about the stereotype that it is a party for Welsh speakers (McAngus, 2014b: 91-95), and part of its internal transition to the status of government was 
concerned with challenging some of these stereotypes. However, the ministerial portfolios that it decided, or indeed was compelled, to take meant that this process was somewhat hampered.

In 1942, John MacCormick, one of the co-founders of the SNP, split from the party to set up the crossparty 'Scottish Convention' in an attempt to achieve home rule for Scotland through working with other parties as a pressure group (Finlay, 1994: 230-231). By leaving the party, MacCormick solved a major and divisive strategic debate within the party's leadership and allowed the SNP to begin its development into a more modern party organisation under the guidance of the party's new Secretary, Robert Maclntyre (Finlay, 1994: 234). The party struggled throughout the 1950s in both electoral and financial terms (Lynch, 2013). By the 1960s, the party was beginning to turn the corner in electoral terms but was still reticent in terms of adopting a distinct position on the left-right spectrum (Lynch, 2009: 623-624). The 1960s did see, however, the party begin to develop policies on a wide-range of issues (Lynch, 2013: 109-110), although it wasn't until the 1970s that a deliberate push was made to forge those policies into a coherent ideological whole (Mitchell, 1996: 207). The SNP's 1974 general election manifesto made explicit reference to social democracy, and by the early 1980 s the party was describing itself as a moderate, centre-left party (Lynch, 2009: 624). Recent research of the SNP's membership shows that it is indeed a party that is firmly on the centre-left of the ideological spectrum (Mitchell et al, 2012).

Unlike Plaid Cymru, the SNP does not have any firm attachment, real or perceived, to aspects of Scottish culture. There were periods in the party's early history, and indeed in the early 1980s, when 'extreme' groupings concerned with aspects of Scottish heritage and genealogy were active, but these elements were always excluded from the party. Indeed, the SNP is a party that very much promotes a civic conception of Scottish nationalism (Van Der Zwet, 2012). Significant divisions in the party occurred in 
the 1970s regarding the reasons for the party's electoral successes in that period. The SNP's 11 MPs after the October 1974 general election had largely been elected in Conservative seats, but the party's National Executive was largely left-wing and saw the potential of the SNP in traditional Labour heartlands (Lynch, 2013: 140) where, despite not winning many seats, had come second in many of them (Mitchell, 2009b). From the 1980s, the SNP has been firmly placed on the centre-left and has promoted itself as the natural alternative to the Labour party. Indeed, the two parties remain very close ideologically, with the constitutional status of Scotland being the main dividing line between them (Wheatley et al, 2012). Therefore, the SNP has certainly not been a niche party for decades given its ideological positioning, broad policy profile and engagement with normal lines of political division.

\section{Adapting to devolution}

Referendums were held in both Wales and Scotland in 1997 asking whether or not devolved should be granted. Both referendums were successful, although the result in Wales was exceptionally close. The type of devolution that was offered differed quite substantially: while the Scottish parliament had legislative freedom over a significant range of domestic policy, the NAW had a much weaker form of devolution in that it could only amend primary legislation. Nevertheless, the creation of both of these institutions radically transformed the opportunity of both Plaid Cymru and the SNP overnight in the sense that both parties could now seriously entertain the idea of becoming parties of government at the sub-state level.

Both parties performed well at the inaugural devolved elections. The SNP won 35 of 129 seats, whilst Plaid Cymru did even better by winning 17 of 60 seats. At the next round of elections in 2003, both parties struggled, with the SNP losing 8 seats and Plaid Cymru losing 4. Plaid Cymru entered the NAW with the aim of influencing policy-making in the new institution. However, the party fell short of its 
policy ambitions and tensions within the party over its failure to articulate a more left-wing agenda and a lack of focus on the party's 'traditional' issues. Furthermore, the state-wide parties in Wales successfully moved on to 'nationalist' ground and thus took issues away from Plaid Cymru that traditionally belonged to them (Elias, 2009b). After the 2003 election, the party underwent a process of soul-searching regarding its purpose in Welsh politics: was Plaid Cymru a pressure group that existed to promote traditional interests such as the language and self-government for Wales, or was it an aspiring party of government (Elias, 2009b: 127)? The party held an election to determine its president, and the winner, Dafydd Iwan, signalled a party that wished to focus on a 'narrow' set of traditional issues, something that Elias (2009b: 128) suggests meant resorting to a more 'niche' political strategy. Despite these developments, Plaid Cymru entered governmental office in 2007 as a junior partner in coalition with Labour. As the next section will show, this process was used by party elites as a didactic mechanism through which the wider party could see the benefits of being a party of government and maintaining a mainstream profile.

The SNP's problems leading into the 2003 election were largely organisational ones. The party still retained an organisational structure that was largely unchanged from the 1960s, and branch delegates were responsible for electing the order in which candidates would be ranked on the party lists. A bitter period of internal wrangling began around the summer of 2002, and many of the party's most recognisable figures were placed so far down the lists that it became practically impossible for them to be elected (Mitchell, 2002). There are other reasons for the party's poor electoral performance, one being the success of smaller parties such as the socialists (Lynch, 2013: 253). However, the party's leader at the time, John Swinney, put a lot of blame on the internal wrangling and lacklustre organisational structures and took the opportunity to reform the party. The party underwent significant 
organisational reforms in 2004, a process that resulted in a more professional party organisation (McAngus, 2014b; Mitchell et al, 2012). John Swinney stood down as SNP leader later that year after a poor European election result, and paved the way for the return of the party's former leader, Alex Salmond. The SNP, like Plaid Cymru, became a party of government in 2007 . The party won 47 seats at the 2007 Scottish election, one more than Labour, on the back of a populist and pragmatic policy programme (Lynch, 2009). A coalition with the Liberal Democrats was sought but never materialised, and the SNP formed a single-party minority government. The next section will discuss how elites viewed this transition. Like Plaid Cymru, SNP elites were keen to show the public, through utilisation of governmental office, that the SNP was a trustworthy and 'normal' political party. .

\section{What becoming a party of government meant for party elites - the search for a new status}

Throughout its history, the SNP has been ridiculed by its political opponents, in particular by its fiercest political rivals: Scottish Labour (Hassan, 2009). In the early 1960s, in the context of the SNP attempting to gain an electoral foothold at the local level, the then Conservative Secretary of State for Scotland, Michael Noble, jibed that the party 'couldn't run a toffee shop' (Mitchell, 1996: 201). As well as the party's credibility, its policy profile also came under attack. 'SNP: Still No Policies' was an insult used by the parties political opponents, and this jibe played a part in the party's determination to develop its policy profile in the late 1960s and into the 1970s (Mitchell, 1996: 207). Furthermore, the SNP's electoral success in 1974 was something of a poisoned chalice for the party in that there was confusion over who had actually voted for them. The party's breakthrough had been largely at the expense of Conservative seats, but the party came to the 'absurd' conclusion that it was Conservative voters who were backing them (Mitchell, 1996: 209). The party had in fact won over an anti-Conservative coalition of Labour and Liberal defectors in these seats, and this misinterpretation allowed Labour to brand the SNP as 'Tartan Tories' (Lynch, 2013: 138), a label which stuck with them for the next couple of decades. 
In the first election to the Scottish Parliament in 1999, the SNP's raison d'etre of independence was highlighted by Labour in the infamous slogan 'divorce is an expensive business' which was adopted as part of 'a hard, abrasive, populist anti-Scottish Nationalist message' (Hassan and Shaw, 2012: 93). These are just examples of the most inventive jibes that have been levelled at the SNP over its lifespan. Even today, senior Labour figures still claim the SNP advocates a 'narrow nationalism' that is anathema to the values of solidarity (The Scotsman, $23^{\text {rd }}$ September 2014).

The SNP's success at the 2007 Scottish election was evidence of just how much the party had become a mainstream political force given that their electoral success was based, largely, on the notion that they were perceived by the electorate as the most competent and able potential party of government in relation to Labour (Johns et al, 2009). However, the party was keen to illustrate through governmental office that the party had 'grown up' (Interview, SNP MSP), was 'no longer a single-issue party' (Interview, SNP MSP), and had long since shed any 'fringe or mickey mouse party' characteristics (Interview, SNP MSP). Although these statements can be seen in the context of trying to use governmental status to overcome and dispel some of the jibes mentioned above, they also represent the finality of the organisational reform process began by John Swinney in 2003. After the poor election, Swinney addressed the party's National Council and stated that 'in far too many areas of Scotland [the SNP lacks] that electoral credibility' (Swinney, 2003). By winning the most seats 2007 and defeating Labour, the party truly had matured and come of age after a difficult period of internal strife in the lead up to and after the 2003 Scottish election. This process cemented a vote for the SNP as a vote for a party of government, not a protest vote (Interview, SNP MSP). This result had, according to one MSP, made other voters less fearful of voting for the SNP and had helped the party win its unprecedented majority at the 2011 Scottish election (Interview, SNP MSP). Through becoming a party of government for the 
first time, and thus embracing a new status and identity (Deschouwer, 2008), SNP elites saw government as mechanism to promote their party as having come of age and become truly 'normal'. Despite having achieved such a status already when viewed from the outside, elites in the party saw governmental office as an opportunity to confirm this state of affairs and promote the party as such.

The SNP's quest for credibility was not an end in itself. Not knowing the electoral success that would come in 2011, the SNP was focussed on playing the long game over independence (Lynch, 2013). This strategy is recognisable in interview data. According to an MSP, 'if you show that Scotland can run its own government' and 'manage resources, deliver policies and show ambition' then you can inspire confidence in Scotland's ability to run its own affairs (Interview, SNP MSP). Furthermore, one cabinet minister remarked that being in government provides the ability to demonstrate that '[Scotland] can govern [itself] better than London' and find 'Scottish solutions for Scottish problems' (Interview, SNP MSP). There is a sense within the SNP that overcoming much of the electorate's 'fear' of Scottish independence is one of the biggest issues facing the party, and emphasising competence is part of the strategy to show independence as less of a 'leap in the dark' and more of a 'natural progression from where [Scotland is] now.' (Interview, SNP MSP) If the SNP could show that it could 'do well' with the powers it had then the electorate will 'trust you in saying that more are necessary' (Interview, SNP MSP).

In late August 2007, the SNP as the Scottish Government released a report on the first 100 days of the parliamentary term, stating that they had 'published a White Paper on Independence and further responsibilities for the Scottish Parliament', as well as 'a draft Bill for a referendum' and had begun 'a national conversation about the future of Scotland's Parliament and Government.' (Scottish 
Government, 2007). Without the majority needed to pass a bill which would trigger a referendum on independence, the SNP aimed to use governmental office to promote its primary goal by relaying the impression of governmental competence which would boost support for the SNP and independence; and use governmental office as a direct institutional platform to hold a referendum on Scottish independence (Harvey and Lynch, 2012), although it turned out to be unsuccessful in achieving this second aim in the 2007-2011 parliamentary term. Overall, the promotion of competency and normality was important for the SNP, but this desire to be seen in a positive light was also intended to promote the party's primary goal of Scottish independence.

Back in the 1930s, Labour dismissed Plaid Cymru as 'pro-fascist rabble' (Sandry, 2012: 62), a label that was to stick with the party despite the unfounded and untruthful nature of the charge (Wyn Jones, forthcoming). By the 1966 general election, the perception that the party was still a 'fringe movement of extremists" was widely held, something that made the party's success in the Carmarthen by-election the same year all the more surprising (Morgan, 1981: 386). After 1966, Labour saw Plaid Cymru as an immediate electoral threat, and Plaid Cymru winning two seats and then three seats in the two respective general elections in 1974 showed that these fears were genuine. Figures within the Labour party described Plaid Cymru as a 'party of academic dreamers', and the idea of devolution in the 1970s was met with some fierce hostility from within the Labour party itself, the most extreme claims stating that devolution was a breeding ground for anti-Englishness and 'English haters' (Edwards, 2011:196197). Plaid Cymru's goal of Welsh self-government was associated with such sentiments, and the devolution proposals in the 1970s were attacked from within the Labour party on the basis that, amongst other things, it would facilitate the imposition of the Welsh language on non-Welsh speakers and place Wales on the 'slippery slope' towards political separation from the UK (Mitchell, 2009: 155). 
These jibes and perceptions are just examples of the stereotypes that Plaid Cymru have historically been associated with. However, the party has had a chronic association with the Welsh language, with its electoral strength in the North and West of Wales closely correlated with these areas being where the Welsh language was, and still is, most widely spoken (McAllister, 2001: 76-77). The perception that Plaid Cymru is a party for Welsh speakers has been ingrained into the Welsh psyche by events such as Gwynfor Evans' threat to starve himself to death in 1980 if a Welsh language television channel, promised by Margaret Thatcher's government, was not created. These perceptions have persisted: English-speakers feel that the party cares less about them compared to how they care about Welsh speakers (McAngus, 2014b: 91-95). These conceptions are perpetuated by internal party politics within Plaid Cymru itself: the election of Dafydd Iwan as the party's President in 2005, for example, represented a desire by party activists to re-assert the centrality of traditional 'Plaid' issues to the Welsh nationalist project (Elias, 2009c: 543). Even in the run-up to forming a coalition with Labour, a leaked Labour document described Plaid as 'leaderless, rudderless and hopeless' and 'a shambles which could not run a cockle stall, let alone a country' when both parties were negotiating the terms of the One Wales Government in the summer of 2007 (Western Mail, 27th June 2007). Like the SNP, Plaid Cymru has spent most of its political life on the sidelines and has endured taunts and misconceptions as a result. However, Plaid Cymru also saw the potential of governmental office to dispel some of these misconceptions and use its new status as a mainstreaming mechanism.

Plaid Cymru elites believed that governmental status would show the electorate that the party was mature, trustworthy and constructive. On his acceptance as Deputy First Minister (DFM), leaun Wyn Jones stated Plaid had moved from being an 'opposition party' that existed 'to place pressure on other 
parties to progress matters for Wales', to a partner in an 'innovative and stable Government that would serve the people of Wales for four years.' (Welsh Government, 2007a) Plaid was now a party that could no longer be 'accused of never being able to do anything' (Interview, Plaid Cymru AM) and could be 'trusted in government' (Interview, Plaid Cymru AM). One AM even suggested that Plaid Cymru could now be considered a 'more normal party alongside other parties in Wales' (Interview, Plaid Cymru AM), while a government minister in the One Wales Government stressed that the party was keen to show the electorate that it could engage in policy areas that were 'mainstream' and not 'traditional to Plaid', such as the language and the constitution (Interview, Plaid Cymru AM). Furthermore, becoming a party of government was a process by which the party itself could learn and evolve. In the opinion of a senior Plaid Cymru elite, governmental status would help Plaid mature as an organisation and provide sceptical elements in the party with an understanding of what government entailed (Interview, Plaid Cymru AM). The chance to simply sit at the cabinet table and undertake the business of governing Wales was perceived as vitally important for Plaid as a party (Interview, 29th September 2011). This belief is a manifestation of the debate within the party (discussed above) about Plaid Cymru's ultimate purpose in Welsh politics. This sentiment clearly represents the strand of opinion in the party that Plaid Cymru is a political party that contests elections for the purpose of becoming a party of government. The lack of these sentiments in SNP interview data suggests that the process of fundamental organisational reform that SNP underwent in 2004 largely set the party on a 'government-in-waiting' path, a process that occurred to a much lesser extent in the in Plaid Cymru between 2003 and 2007 (Elias, 2011). One AM who happened to one of the Assembly group who wished to remain in opposition in 2007 and operate on a 'supply and confidence basis' stated that they became convinced of the benefits of being in government as time went on (Interview, Plaid Cymru AM). Therefore, there is evidence that this strategy actually worked, at least with some previously sceptical elements of the party. 
Unlike the SNP, Plaid Cymru entered into coalition with a larger party after the 2007 Welsh election. Labour had actually been sworn in as a single-party minority government, but Labour's leader at the time, Rhodri Morgan, was keen to secure a majority through coalition. As a result of the negotiations with Labour that would lead to the signing of the One Wales Agreement and the formation of the One Wales Government, Plaid Cymru took up cabinet ministerial posts in Rural Affairs, Economy and Transport and Culture and Heritage, as well as a 'junior' housing minister role. There was a sense of satisfaction about the portfolios that the party ended up and with the outcome of the negotiations (Interview, Plaid Cymru AM), although the ministerial options that the party had would undoubtedly have been constrained by the fact that Labour had already formed a government. Despite this, a defence of the portfolios that were gained on the basis that two fairly large spending briefs (housing and the economy) were acquired (Interview, Plaid Cymru AM),

However, a number of elites felt that two of the portfolios (Culture and Heritage, and Rural Affairs) simply reinforced certain stereotypes of Plaid Cymru. According to one AM, 'language and the countryside are Plaid Cymru in everyone's mind' and the party should have only accepted one of these 'stereotype reinforcing' portfolios (Interview,Plaid Cymru AM). Another AM reiterates this position, stating that the party was appealing to its core vote by taking these portfolios and that Health or Education should have been sought instead (Interview, Plaid Cymru AM). However, the decision to take those particular portfolios has been defended on the basis that Labour had shown a 'lack of commitment' to the Welsh language' in the 2003-2007 period and that rural affairs was important because it affected areas where Plaid Cymru holds seats in both Wales and at the UK level (Interview, Plaid Cymru AM). 
Because of the history of the party, coupled with the (assumed) feelings and preferences of the party membership, Plaid Cymru was almost institutionally conditioned to take the stereotypical portfolios (cf. Browne and Feste, 1975). According to literature on the distribution of ministerial posts in coalition government, appointed ministers gain substantial control over agenda-setting and policy output (Austen-Smith and Banks, 1990; Laver \& Shepsle, 1990: 874; Hindmoor, 2006: 62), and government was an opportunity to legislate in such areas. On entering government, the party's then Culture and Heritage minister, Rhodri Glyn Thomas, explicitly stated that Plaid Cymru would 'use the Assembly's new powers to strengthen the position of the language' (Welsh Government, 2007b). Indeed, the One Wales Government passed the Welsh Language Measure in 2011 which gave Welsh and English equal and official status in Wales. Despite clearly wishing to use governmental status as a mechanism to overcome stereotypes, Plaid Cymru placed heavy emphasis on its primary goals, and its behaviour on entering into government was bound by those goals. As well as the importance that the party placed on the Welsh Language, which did indeed facilitate internal hostilities during the One Wales Government (Elias, 2009b: 544), the party's period in office became dominated towards the end of the term by the referendum on further powers for the NAW (McAngus, 2014a). Unlike the SNP who were able to 'detach' the issue of the referendum, and thus their primary goal of independence, from many of their political and electoral activities (McAngus, 2014b), Plaid Cymru's period in office became defined by their primary goals. Although the party achieved significant policy success in office, they were not able to disassociate themselves from constitutional or language issues to the degree that some party elites wanted.

\section{Conclusion}

The hypothesis that was outlined earlier in this paper has been confirmed through empirical analysis. Elites in Plaid Cymru and the SNP used the capacity, platform and status of governmental office to 
promote the mainstream credentials of their parties. Both parties had long since become mainstream actors in terms of their policy development, ideological placement and engagement with non-SNRP specific issues. Nevertheless, crossing the threshold of governance was an opportunity, not previously available, to exhibit and prove that the parties did not live up to the stereotypes that their political opponents had painted of them previously. This process was common in both parties. However, the process was inhibited in the case of Plaid Cymru due to the ministerial portfolios that the party took up on becoming a junior coalition partner. Some party elites were of the opinion that the party had to be seen to pushing for the implementation of its primary goals, but others felt that by taking up the portfolios that it did the party was simply perpetuating the stereotypes that it aimed to dispel. The SNP did not face these pressures due to the fact that it entered into government alone, but also because it does not promote cultural issues as a primary goal and is able to 'detach' the issue of independence as a referendum on the issue acts as a safety net for a potentially sceptical electorate.

However, there are some important differences between the parties that were investigated in this paper. The SNP had gone through a painful process of organisational reform in 2004 and as a result had committed itself to being an alternative party of government. The party duly entered into government in 2007 and was keen to use this new status to show the public that it was a trustworthy and competent party. Acting in this way was deliberate in the sense that the party had the wider ambition of using governmental office as a mechanism to steer Scotland towards independent statehood. Plaid Cymru elites, unlike SNP elites, stressed the importance of using governmental status as a tool through which party members could learn how to be a more mature and effective political party that existed to shape policy and utilise political power. These sentiments can be interpreted as a response to the period between 2003 and 2007 when, as Elias (2009b) describes, the party struggled with its status in Welsh 
politics and reverted back to the promotion of certain 'niche' characteristics. A number of elites were keen to promote Plaid Cymru as a political party and not as a pressure group, and shift the balance between the three 'faces' of the party towards the party in public office (Mair, 1994: 4). Interview evidence suggests that this strategy was at least partly success, and Plaid Cymru's new leader as of 2012, Leanne Wood, has made becoming the largest party in the NAW and entering government on that basis one of her key strategic aims. Therefore, perhaps a spell in office will prove to be the catalyst for a longterm and stable strategy by party elites to promote office-seeking behaviour.

Although this paper focuses on only two parties, the theoretical approach and empirical analysis provides the basis for other scholars interested in SNRPs to investigate elite opinion on going into government. The assumption here would be that they would be likely to uncover similar findings. However, as the opening paragraph in this paper stated, parties are the product of their histories and so different SNRPs, as with Plaid Cymru and the SNP, will be expected to experience the crossing of the Rubicon into government in a way that is, to an extent, unique to them. That said, the common themes of trying to prove the party's credentials as credible and mainstream, as well as attempting to undermine stereotypes, is expected to be present. The manner in which these issues manifest themselves historically and impact on the SNRP will be, of course, different in each case given their unique histories and legacies.

\section{Bibliography}

Adams, James, Michael Clark, Lawrence Ezrow, and Garrett Glasgow (2006). 'Are Niche Parties Fundamentally Different from Mainstream Parties? The Causes and the Electoral Consequences of Western European Parties' Policy Shifts, 1976-1998' American Journal of Political Science, 50(3): pp. 513-529.

Austen-Smith, David and Jeffrey Banks (1990) 'Stable Governments and the Allocation of Policy Portfolios' American Political Science Review 84: pp. 891-906 
Bolleyer, Nicole (2008) 'The Organizational Costs of Public Office' in Deschouwer, Kris (ed) New Parties in Government: In Power for the First Time (London: Routledge) pp.17-44

Browne, E.C. \& Feste, K. (1975) 'Qualitative dimensions of coalition payoffs: Evidence for European party governments, 1945-1970' American Behavioral Scientist 18(4): pp. 530-556.

Buelens, Jo and Airo Hino (2008) 'The Electoral Fate of New Parties in Government' in Deschouwer, Kris (ed) New Parties in Government: In Power for the First Time (London: Routledge) pp.157-174

Carter, Catríona and Romain Pasquier (2010) 'Introduction: Studying Regions as 'Spaces for Politics': ReThinking Territory and Strategic Action' Regional and Federal Studies 20: pp. 281-294

Davies, D. Hywel (1983) The Welsh Nationalist Party 1925-1945: A Call to Nationhood (New York: St. Martin's Press Inc.)

Davies, John (1993) A History of Wales (London: Penguin)

De Winter, Lieven and Margarita Gomez-Reino Cachafeiro (2002) 'European Integration and Ethnoregionalist Parties' Party Politics 8: pp. 483-503

De Winter, Lieven., Margarita Gómez-Reino and Peter Lynch (eds.) (1996) Autonomist Parties In Europe: Identity Politics And the Revival of the Territorial Cleavage. Barcelona: ICPS

De Winter, Lieven and Huri Türsan (eds.) (1998) Regionalist Parties in Western Europe (London: Routledge)

Deschouwer, Kris (2008) 'Comparing Newly Governing Parties' in Deschouwer, Kris (ed) New Parties in Government: In Power for the First Time (London: Routledge) pp. 1-16

Duncan, Fraser (2007) “Lately, Things Just Don't Seem the Same': External Shocks, Party Change and the Adaptation of the Dutch Christian Democrats during 'Purple Hague' 1994-8' Party Politics 13(1): pp. 6987

Edwards, Andrew (2009) Labour's Crisis: Plaid Cymru, The Conservatives, and the Decline of the Labour Party in North West Wales, 1960-74 (Cardiff: Welsh Academic Press)

Elias, Anwen (2009a) Minority Nationalist Parties and European Integration: A Comparative Study (New York: Routledge)

Elias, Anwen (2009b) 'Plaid Cymru and the Challenges of Adapting to Post-Devolution Wales', Contemporary Wales, 22(1): pp. 113-138

Elias, Anwen (2009c) 'From Protest to Power: Mapping the Ideological Evolution of Plaid Cymru and the Bloque Nacionalista Galego' Regional and Federal Studies 19: pp. 533-557

Elias, Anwen (2011) 'Plaid Cymru' in Elias, Anwen and Fillippo Tronconi (eds) From Protest to Power: Autonomist parties and the Challenges of Representation (Vienna: Wilhelm Braumüller) pp. 259-282

Elias, Anwen and Fillippo Tronconi (2011a) 'From Protest to Power: Autonomist Parties in Government' Party Politics 17(4): pp. 505-524 
Elias, Anwen and Fillippo Tronconi (2011b) 'Introduction: Autonomist Parties and the Challenges of Political Representation' in Elias, Anwen and Fillippo Tronconi (eds) From Protest to Power: Autonomist parties and the Challenges of Representation (Vienna: Wilhelm Braumüller) pp. 1-25

Evans, Rhys (2008) Gwynfor Evans: A Portrait of a Patriot (Talybont: Y Lolfa Cyf.)

Finlay, Richard (1994) Independent and Free: Scottish Politics and the Origins of the Scottish National Party 1918-1945 (Edinburgh: John Donald Publishers Ltd)

Finlay, Richard (2009) 'The Early Years: From the Inter-War Period to the Mid-1960s' in Hassan, Gerry (ed) The Modern SNP: From Protest to Power (Edinburgh: Edinburgh University Press) pp. 19-30

Freeden, Michael (1998) 'Is Nationalism a Distinct Ideology?’ Political Studies 46: pp. 748-765

Harmel, Robert and Kenneth Janda (1994) 'An Integrated Theory of Party Goals and Party Change' Journal of Theoretical Politics 6(3): pp. 259-287

Harvey, Malcolm and Peter Lynch (2012) 'Inside the National Conversation: The SNP Government and the Politics of Independence 2007-2010' Scottish Affairs 80

Hassan, Gerry (2009) 'The Auld Enemies: Scottish Nationalism and Scottish Labour' in Hassan, Gerry (ed) The Modern SNP: From Protest to Power (Edinburgh: Edinburgh University Press) pp. 147-161

Hassan, Gerry and Eric Shaw (2012) The Strange Death of Labour Scotland (Edinburgh: Edinburgh University Press)

Hepburn, Eve (2009) 'Introduction: Re-Conceptualising Sub-State Mobilization' Regional and Federal Studies 19(4-5): pp. 477-499

Hindmoor, Andrew (2006) Rational Choice (Basingstoke: Palgrave Macmillan)

Jeffrey, Charlie (2009) 'New Research Agendas on Regional Party Competition' Regional and Federal Studies 19: pp. 639-650

Johns, Robert; James Mitchell, David Denver and Charles Pattie (2009) 'Valence Politics in Scotland: Towards an Explanation of the 2007 Election' Political Studies 57: pp. 207-233

Johns, Robert; James Mitchell and Christopher J. Carman (2013) 'Constitution or Competence? The SNP's Re-election in 2011' Political Studies (forthcoming issue)

Laver, Michael and Kenneth A. Shepsle (1990) 'Coalitions and Cabinet Government' American Political Science Review 84: pp. 873-890

Lynch, Peter (1996) Minority Nationalism and European Integration (Cardiff: University of Wales Press)

Lynch, Peter (2009) 'From Social Democracy Back to No Ideology? The Scottish National Party and Ideological Change in a Multi-Level Electoral Setting' Regional and Federal Studies 19: pp. 619-637

Lynch, Peter (2013) The History of the Scottish National Party 2nd Edition (Cardiff: Welsh Academic Press) 
Mair, Peter (1994) 'Party Organizations: From Civil Society to the State' in Katz, Richard S. and Peter Mair (eds) How Parties Organize (London: SAGE) pp. 1-22

McAllister, Laura (2001) Plaid Cymru: The Emergence of a Political Party (Bridgend: Poetry Wales Press Ltd)

McAngus, Craig (2014a) 'Policy and Office at the Expense of Votes: Plaid Cymru and the One Wales Government' Regional and Federal Studies' Regional and Federal Studies 24(2): pp.209-227

McAngus, Craig (2014b) Adapting to Devolution: Governmental Participation and Organisational Reform in Plaid Cymru and the Scottish National Party (Unpublished PhD Thesis, University of Strathclyde)

McDonnell, Duncan and James L. Newell (2011) 'Outsider parties in government in Western Europe' Party Politics 17(4): pp. 443-452

Meguid, Bonnie M. (2005) 'Competition Between Unequals: The Role of Mainstream Party Strategy in Niche Party Success' American Political Science Review 99(3): pp. 347-359

Mitchell, James (1996) Strategies for Self-Government: The Campaigns for a Scottish Parliament (Exeter: Short Run Press Ltd.)

Mitchell, James (2002) 'Political Parties' in Nations and Regions: The Dynamics of Devolution, Quarterly Monitoring Programme, Scotland (August 2002) (Accessed 2nd February 2014) http://www.ucl.ac.uk/constitution-unit/research/research-archive/dmr99-

04/scotland_august_2002.pdf

Mitchell, James (2009a) Devolution in the UK (Manchester: Manchester University Press)

Mitchell, James (2009b) 'From Breakthrough to Mainstream: The Politics of Potential and Blackmail' in Hassan, Gerry (ed) The Modern SNP: From Protest to Power (Edinburgh: Edinburgh University Press) pp. 31-41

Mitchell, James; Lynn Bennie and Robert Johns (2012) The SNP: Transition to Power (Oxford: Oxford University Press)

Morgan, Kenneth O. (1981) 'Rebirth of a Nation: Wales, 1880-1980 (Oxford: Oxford University Press)

Müller-Rommel, Ferdinand (1998) 'Ethnoregionalist Parties in Western Europe: Theoretical Considerations and Framework of Analysis', in De Winter, Lieven and Huri Tursan (eds), Regionalist parties in Western Europe, (London: Routledge) pp. 17-27

Plaid Cymru (2013) Cyfansoddiad/Constitution (Cardiff: Plaid Cymru)

Rahn, Wendy M. (1993) 'The Role of Partisan Stereotypes in Information Processing About Political Candidates' American Journal of Political Science 37: pp. 472-496

Rokkan, Stein and Derek Urwin (1983) Economy, Territory, Identity: Politics in West European Peripheries. London: Sage

Sandry, Alan (2011) Plaid Cyrmu: An Ideological Analysis (Cardiff: Welsh Academic Press)

Scott, John (1990) A Matter of Record: Documentary Sources in Social Research (Cambridge: Polity) 
Scottish Government (2007) Principles and Priorities: The Government's Programme for Scotland September 2007 (Edinburgh: Scottish Executive)

SNP (2009) Constitution of the Scottish National Party (Edinburgh: SNP)

Strøm, Kaare and Wolfgang C. Müller (1999) 'Political Parties and Hard Choices' in Müller, Wolfgang C. and Kaare Strøm (eds) Policy, Office or Votes: How Political Parties in Western Europe Make Hard Decisions (Cambridge: Cambridge University Press) pp. 1-35

Swinney, John (2003) John Swinney MSP address to National Council 07/06/03 (accessed 29th January 2014)http://www.snp.org/media-centre/news/2003/jun/john-swinney-msp-address-national-council$\underline{070603}$

The Scotsman (2014) EU referendum mirrors 'narrow nationalism', 23 $3^{\text {rd }}$ September 2014 (accessed $27^{\text {th }}$ October 2014) http://www.scotsman.com/news/uk/eu-referendum-mirrors-snp-narrow-nationalism-13548780

Toubeau, Simon (2011) 'Regional Nationalist Parties and Constitutional Change in Parliamentary Democracies: A Framework for Analysis' Regional and Federal Studies 21(4-5): pp.427-446

Van Atta, S. A. (2003) "Regional Nationalist Parties and the New Politics: The Bloque Nacionalista Gallego and Plaid Cymru", Regional and Federal Studies, 13: pp. 30-56

Van Der Zwet, Arno (2012) A comparison of civic and ethnic national identities in the Scottish National Party and Frisian National Party and their impact on attitudes towards European integration, immigration and multiculturalism (Unpublished PhD Thesis, University of Strathclyde)

Wagner, Markus (2012) 'Defining and measuring niche parties' Party Politics 18(6): pp. 845-864

Ware, Alan (1996) Political Parties and Party Systems (Oxford: Oxford University Press)

Welsh Government (2007a) Appointment as Deputy First Minister - leuan Wyn Jones Statement (accessed 26th January

2014)http://wales.gov.uk/about/cabinet/cabinetstatements/2007/1570294/?lang=en

Welsh Government (2007b) Priorities for the Heritage Portfolio (accessed 26th January 2014) http://wales.gov.uk/about/cabinet/cabinetstatements/2007/021007rgt/?lang=en

Western Mail (2007) Elis-Thomas attacks 'mindless' Plaid election strategy, 27th June 2007 (accessed 13th February 2014)http://www.walesonline.co.uk/news/wales-news/labour-plaid-couldnt-run-cockle2246734

Wheatley, Jonathan., Christopher Carman, Fernando Mendez and James Mitchell (2012) 'The dimensionality of the Scottish political space: Results from an experiment on the 2011 Holyrood elections' Party Politics (advance online access)

Wyn Jones, Richard (forthcoming) The Fascist Party in Wales? Plaid Cymru, Welsh Nationalism and the Accusation of Fascism (Cardiff: University of Wales Press)

Yin, Robert K. (2009) Case Study Research: Design and Methods 4th Edition (London: SAGE) 
